\title{
Theoretical and experimental analysis of photovoltaic module characteristics under different partial shading conditions
}

\author{
Ali Hussein Numan, Zahraa Salman Dawood, Hashim A. Hussein \\ Department of Electromechanical Engineering, University of Technology, Baghdad, Iraq
}

\begin{tabular}{l}
\hline \hline Article Info \\
\hline Article history: \\
Received Jul 6, 2019 \\
Revised Dec 2, 2019 \\
Accepted Feb 16, 2020 \\
\hline
\end{tabular}

\section{Keywords:}

PV module

Solar radiation

Partial shading,

Power losses

\begin{abstract}
Recently, the renewable energy resources have gained more attention in the electricity sector as promising technology to tackle the depletion in the traditional energy resources. Solar energy grows rapidly due to its vast applications. The performance of Photovoltaic (PV) system is affected by partial shading that results from building, clouds, and fallen leaves. This paper investigates theoretically and experimentally the impacts of various cases of partial shading; such as vertical string, horizontal string, and single cell at environmental conditions on the current-voltage and power-voltage characteristics of $88 \mathrm{~W}$ PV panel. In addition, diagonal shading with multi steps is considered in the analysis. The experiments are conducted with considering various parameters; such as shading position and ratio to validate the simulated results. The results show that at $100 \%$ shading condition, the maximum power drops by $99.36 \%, 43.7 \%$, and $41.15 \%$ for horizontal, cellular and vertical shading at the same solar radiation level comparing with their initial state value. Horizontal string shaded has the highest negative impact on the power and efficiency among other types of shadings. The comparison between the theoretical and experimental results reveals considerable agreement between the theoretical and experimental results.
\end{abstract}

This is an open access article under the CC BY-SA license.

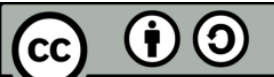

\section{Corresponding Author:}

Ali Hussein Numan

Electromechanical Engineering Department

University of Technology

Al-Sana'a Street,Tel Mohammed,Baghdad,Iraq

Email: 50059@uotechnology.edu.iq

\section{NOMENCLATURE}

PV Photovoltaic

I current (A)

Iph photon current (A)

Irs reverse saturation current of diode (A)

$\mathrm{V} \quad$ voltage $(\mathrm{V})$

Rs $\quad$ series resistance of PV cell $(\Omega)$

A ideality factor

VT junction thermal voltage

Ns number of cell in series

$\mathrm{K} \quad$ Boltzmann constant $\left(1.3806503 \times 10^{\wedge}-23 \mathrm{~J} / \mathrm{K}\right)$

Tc cell temperature $\left({ }^{\circ} \mathrm{C}\right)$

Q electron charge $\left(1.6021765 \times 10^{\wedge}-19 \mathrm{C}\right)$ 
Fs shading factor

Gt,s shaded surface irradiances $\left(\mathrm{W} / \mathrm{m}^{2}\right)$

Gt unshaded surface irradiances $\left(\mathrm{W} / \mathrm{m}^{2}\right)$

SA shading area

Imax current at the maximum power point (A)

Vmax voltage at the maximum power point $(\mathrm{V})$

Pmax power at the maximum power point (W)

$\triangle \mathrm{P} \quad$ power loss of $\mathrm{PV}$ panel (W)

F.F fill factor

\section{INTRODUCTION}

The emission of carbon from the traditional electrical power generation technology is one of the most important reasons that lead to employ the renewable energy as alternative sources of electrical power generation. Solar energy is the best choice for electricity generation [1] because it is clean [2], cheap [3], silent [4], abundant and environmentally friendly energy resources [5].

Among different forms of renewable energy, PV represents one of the most promising renewable energy in the world [6,7] due to its great advantages; such as zero emission of greenhouse gases, low maintenance cost, not rotating or moving parts $[8,9]$. A PV cell is basically a semiconductor diode with a large barrier layer exposed to light allowing portion of the energy in the light photons arriving at the cell convert directly to DC electrical power [10]. The most notable factors that have a clear impact on the performance of PV system are: Partial shading, dust [5], sand [11], temperature [12], and solar radiation [13]. Partial shading is the most common encountered problem in a PV system. In this phenomenon, the received sunlight is reduced significantly and results in lower system efficiency [14]. In the design stage, the shadow of nearby objects avoided as possible. However, parts of PV module face unexpected shadows; such a sun melted snow, bird dung, fallen leaves, the neighboring buildings, towers, and passing clouds [15, 16].When the PV module partially shaded, the shaded cell operates at current levels lower than unshaded cell. As consequence, the shaded cells are forced into reverse bias and begin consuming power instead of generation power. This lead to undesired increase in cell temperature this is lead to localized overheating (hot spot). When this temperature reaches the critical limit, the effected cell (shaded cell) can be damaged [17].Passive and active methods are used for decreasing the power losses which are caused by partial shading. In the first method, the bypass diode is connected in antiparallel with the photovoltaic cells in order to pass the current and avoid the destructive impact of shading. Current flow in the diode causes losses in power, therefore, it is not possible to avoid losses completely. On the other hand, the dynamic reconfigurations between the panels of photovoltaic represent second method (active method) [18, 19]. H. H. Khaing et al [20]: Studied the effect of different partial shading on four various types of PV modules that involve amorphous thin-film, CIGS thin-film, CdTe thin-film and multi-crystalline PV modules. The module tested along the length side and along the breadth side with different shading rate varied from $10 \%$ to $60 \%$ from the PV area with increase of $10 \%$. The result showed that shading along the breadth side more effected than shading along it's length side. G. S. Reddy et al. [21] Presented PV module model by MATLAB/ Simulink to analyze their performance under nonuniform irradiance condition. Moreover, Various PV array simulation schematic could be created by the proposed model, and parameters of irradiance of each PV module can be set independently. Different simulation process is conducted and compared for different array configurations ( 2 series, 3 series, 2 series $\times$ 2parallel and 3 series $\times 2$ parallel) under nonuniform irradiance conditions of I-V and P-V characteristics curves. M. Abdullah et al [22], investigated the impact of shading on the effectiveness of PV panel. The experiments have been accomplished with a 90-W solar panel under constant and changeable irradiations. Horizontally shaded area which changed from 0 to $80 \%$ has been applied to detect the impact of varying irradiation at appointed shading points. The results showed that for each $100 \mathrm{~W} / \mathrm{m} 2$ increase in radiation level leads to enhance the output power by $3.89 \mathrm{~W}, 3.37 \mathrm{~W}, 2.27 \mathrm{~W}$, and $2.02 \mathrm{~W}$ at $0 \%, 25 \%, 50 \%$, and $75 \%$ shaded area respectively. In addition, the efficiency has been raised by $0.29 \%, 0.27 \%, 0.25 \%$, and $0.22 \%$ at $0 \%, 25 \%, 50 \%$, and $75 \%$ shaded area respectively. The drop in output power and efficiency were $12.41 \mathrm{~W}$ and $2.3 \%$ respectively when the shading area increased by $10 \%$. However, this study considers the horizontal shading and ignored the other types of shading. F. Bayrak et al (2017) [23], analyzed thermodynamic and electrical performance under the shading shape and shading ratios on $75 \mathrm{~W}$ polycrystalline PV. Horizontal, vertical and single cell shading at different percentage were applied. The results showed that at $100 \%$ shading rate, the power losses were $99.98 \%, 66.93 \%$ and $69.92 \%$ for horizontal, vertical and cellular shading respectively. The gap of this research is that the results are obtained from a practical study only without simulating study. Gutierrezet al [24] presented the effortless approach to model and analyze the performance of PV module under partial shading using shading ratio. The shadow opacity and characteristics of shaded 
area integrated in this approach. J. C. Teo et al (2018) [25], investigated the partial shading effect and the critical point that reduced the sensitivity of shading heaviness. Under various numbers of shaded modules and shading heaviness, The P-V characteristics showed that the PV string became impervious to gravity shad when the irradiance of shaded panels arrived a critical point. The results showed that when irradiation on the shaded modules on the PV system was between 1000 and $700 \mathrm{~W} / \mathrm{m} 2$, the power dropped by about $6.2 \%$ for each $100 \mathrm{~W} / \mathrm{m} 2$ drops in the irradiation. However, when irradiation was between 700 and $0 \mathrm{~W} / \mathrm{m} 2$, each 100 $\mathrm{W} / \mathrm{m} 2$ drops in the irradiation, leads to drop the power by $0.24 \%$. In [21] and this research, the results obtained from MATLAB/SIMULINK did not validated experimentally. In the present paper, different cases of partial shading with different percentages are analyzed experimentally and theoretically to determine its impact on power and efficiency of mono crystalline PV panel with 36 series connected cells and three bypass diode. Insulated material is employed as shading element in different cases with different percentage of shaded area. The I-V recorded and P-V calculated before and after applying shadow is utilized to find the power loss corresponding to this shadow.

\section{MODELING OF PHOTOVOLTAIC MODULE}

PV module is the basic unit of power PV generation system. PV module has non-linear characteristics which depend on solar radiation and cell temperature. In this paper, PV module with 36 series connected solar cell is chosen. Figure 1. Shows the PV module model that is employed in this study. Besides, the irradiance $(\mathrm{G})$ and temperature $(\mathrm{T})$ with the electrical characteristics parameter of PV module such as, open circuit voltage (Voc), short circuit current (Isc) are shown in the figure. It is having 23.42V, 5.192A and 1.5 as open circuit voltage (Voc), short circuit current and ideality factor respectively, while series resistance value (Rs) is $0 \mathrm{ohm}$. Different cases are carried out using Matlab/Simulink to determine I-V and P-V characteristics (Table 1). To develop the model of PV, the solar cell block is taken from Sim Electronics block set-Matlab. The parameters of solar cell are defined in equations (1) and (2) [25].

$$
\mathrm{I}=I_{p h}-I_{r S}\left[\exp \left(\frac{V+I R_{S}}{a V_{T}}\right)-1\right]
$$

Where:

$$
V_{T}=\frac{N_{S} k T_{C}}{q}
$$

The output powr is [26]

$$
P_{m}=I_{\max } V_{\max }
$$

Fill factor (FF) represents the ratio of maximum power divided by the open circuit voltage and short circuit current [26]

$$
F . F=\frac{P_{m}}{P_{t h}}=\frac{V_{\max } I_{\max }}{V_{o c} I_{s c}}
$$

$I, I_{P h}$ and $I_{r s}$ are the output, photo-generated and the diode saturation currents respectively, $V$ is the output voltage, $R_{S}$ is the series resistance, $N_{S}$ is the number of cells, $V_{T}$ is the junction thermal voltage, $A$ is the ideality factor, $k$ is the Boltzman constant $(1.3806503 \times 10-23 \mathrm{~J} / \mathrm{K}), T$ is the cell temperature and $q$ is the electron charge $(1.6021765 \times 10-19 \mathrm{C})$.

Different cases were conducted as illustrated in Table 2. The adopted PV module includes 36 solar cell which are divided into two group, each group consist of 18 cells. Different solar irradiations and constant temperature $\left(25^{\circ} \mathrm{C}\right)$ were applied to find their effect on the I-V and P-V curve of the PV model. Shading factor (FS) represents the ratio of irradiance on the shaded Surface $\left(G_{T, S}\right)$ to the irradiance on the unshaded surface $\left(\mathrm{G}_{\mathrm{T}}\right)$ [27].

$$
\mathrm{F}_{\mathrm{S}}=\frac{G_{T, S}}{G_{T}}
$$


Table 1. Cases studies carried out

\begin{tabular}{cccc}
\hline Case study & \multicolumn{2}{c}{ Solar Cell Irradiance $\left(\mathrm{W} / \mathrm{m}^{2}\right)$} & $\begin{array}{c}\text { Shading Factor } \\
\text { (FS) }\end{array}$ \\
\hline Case 1 & Unshaded group $(18$ cells $)$ & Shaded group $(18$ cells $)$ & 1 \\
Case 2 & 1000 & 1000 & 0.8 \\
Case 3 & 1000 & 800 & 0.6 \\
Case 4 & 1000 & 600 & 0.4 \\
Case 5 & 1000 & 400 & 0.2 \\
Case 6 & 1000 & 200 & 0 \\
\hline
\end{tabular}

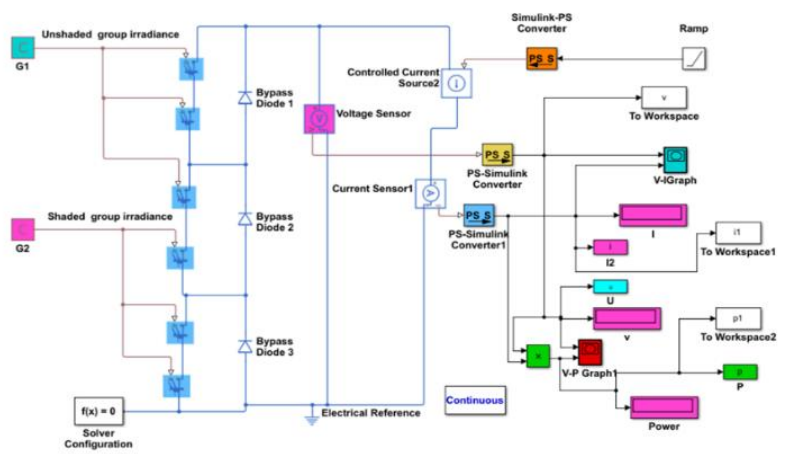

Figure 1. Photovoltaic module model with three bypass diodes

In addition, other cases were considered by applying different irradiation level on three groups of solar cells (each group 12 cells) as shown in Table 2 the model in Figure 1 used in these cases with simple changes.

Table 2. Illustration of random radiation levels for PV module.

\begin{tabular}{cccc}
\hline Case study & Unshaded group A (12 cells) & $\begin{array}{c}\text { Solar Cell Irradiance }\left(\mathrm{W} / \mathrm{m}^{2}\right) \\
\text { Shaded group B }(12 \text { cells })\end{array}$ & \begin{tabular}{c} 
Shaded group C $(12$ cells $)$ \\
\hline Case1
\end{tabular} Case 2 $_{\text {Case 3 }}$ \\
Case 4 & 1000 & 1000 & 1000 \\
Case 5 & 1000 & 900 & 800 \\
Case 6 & 700 & 800 & 600 \\
Case 7 & 800 & 600 & 200 \\
Case 8 & 300 & 950 & 300 \\
& 300 & 500 & 700 \\
& 200 & 200 & 400 \\
\hline
\end{tabular}

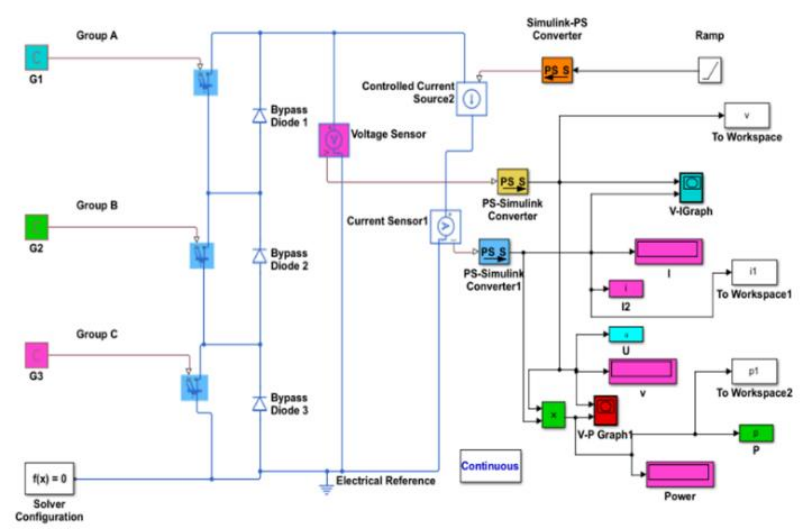

Figure 2. Photovoltaic module model (three group with different irradiation levels) 
Figure 3 shows the PV module, the vertical string shading with $100 \%$ shading area are applied to the model and the results are compared with the experiment results.

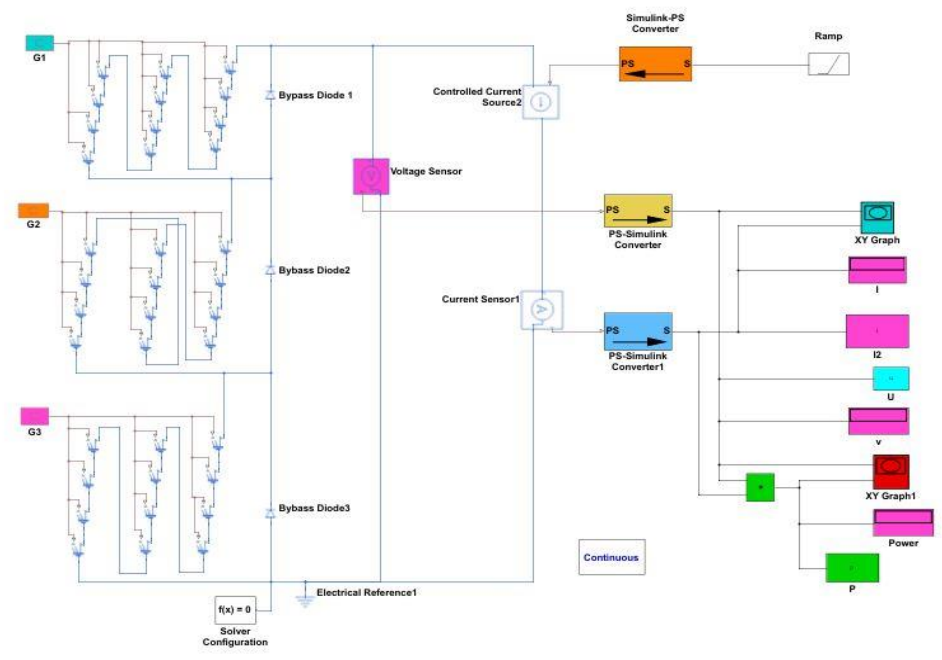

Figure 3. PV module and the experiment results

\section{EXPERIMENTAL SETUP}

In order to obtain the I-V and P-V characteristics of the PV panel under partial shading, the current and voltage were measured. Solar radiation and ambient temperature affect these characteristics therefore; it is necessary to measure these parameters. At environmental conditions, the change in atmospheric condition may lead to rapid change in the solar radiation therefore; the data must be recorded quickly in short time as possible.

Figure 4 shows the experimental setup, where the experiment was set up in Baghdad $\left(33.33^{\circ} \mathrm{N}\right.$ latitude and $44.39^{\circ} \mathrm{E}$ longitude) for collecting the required data. The utilized PV pane is Monocrystalline PV panel with 36 cells connected in series, where each 12-cell connected to one bypass diode. The panel is placed on a mobile metallic holder and it is installed to face the south with an inclination of 31.2. Table 3 explains the electrical characteristics of the PV panel under standard test condition. The required data are radiation intensity, ambient and module temperatures, wind speed and relative humidity therefore; two digital multi- meters used to measure the current and voltage. Thermocouple type $\mathrm{k}$ was used for obtaining the panels temperature by using a digital data recorder. Relative humidity and ambient temperatures were measured by using UNI-T UT332 digital Thermo-hygrometer devise. The measurement of wind speed was obtained using wind gage type Kaindl Wind master 2.

Solar radiation was measured by solar meter pyrometer type TES $1333 \mathrm{R}$ and rheostat $(100 \mathrm{~W}, 10 \Omega)$ were used as load to measure the maximum current and maximum voltage. Many experiments were carried out in clear sky condition during September, 2018 to investigate partial shading on the panel. Different cases with different percentage of shading were applied on the panel by using non-transparent material as shading element to closing as $0,25,50,75,100 \%$ shaded area of horizontal string, vertical String and single cell as illustrated in Figure 5 and 6. Moreover, diagonal shading also investigated as shown in Figure 7.

Table3. Electrical characteristic of monocrystalline solar panel

\begin{tabular}{lcc}
\hline \multicolumn{1}{c}{ Designation } & Abbreviation & Values \\
\hline Maximum power & Pmp & 88 \\
Open circuit voltage & VOC & $23.42 \mathrm{~V}$ \\
Short circuit current & ISC & $5.192 \mathrm{~A}$ \\
Voltage at maximum power & $\operatorname{Vmp}$ & $18.33 \mathrm{~V}$ \\
Current at maximum power & $\operatorname{Imp}$ & $4.801 \mathrm{~A}$ \\
Voltage temperature coefficient & $\mathrm{Kv}$ & $-2.10 \mathrm{mV} / \mathrm{cell} /{ }^{\circ} \mathrm{C}$ \\
Current temperature coefficient & $\mathrm{Ki}$ & $15 \mathrm{micro} \mathrm{A} / \mathrm{cm} 2 /{ }^{\circ} \mathrm{C}$ \\
No. of cells connected in series & $N S$ & 36 \\
\hline
\end{tabular}




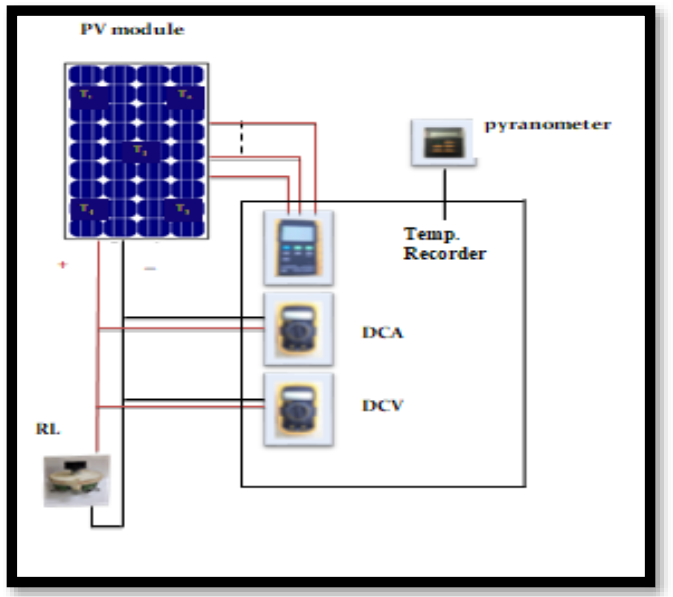

Figure 4. The schematic view of the experimental setup
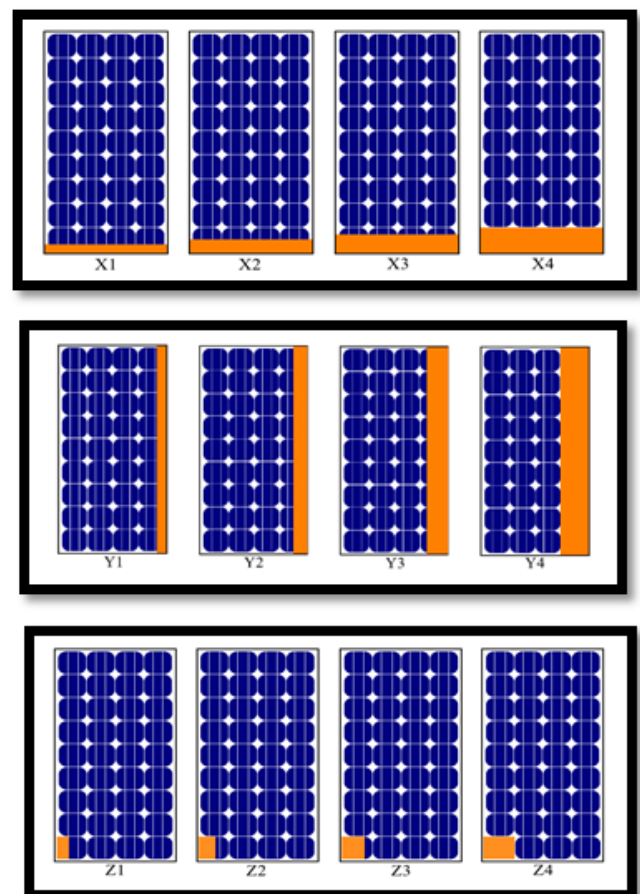

Figure 5. Different percentage of shading for horizontal string, vertical string and single cell by employed insulated materials; (X1) SA=25\%, (X2) SA=50\%, (X3) SA=75\% and (X4) SA=100\%, (Y) SA=25\%, (Z1) $\mathrm{SA}=25 \%$.

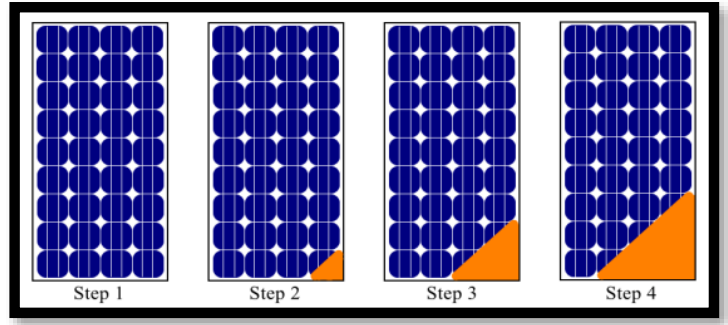

Figure 6. Diagonal shading profile of the photovoltaic panel with different steps 

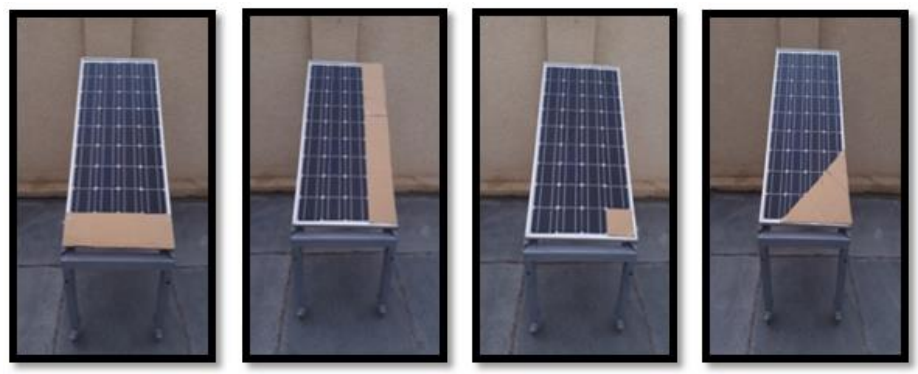

Figure 7. PV panel with different cases of shading (A) horizontal, (B) vertical, (C) single cell and (D) diagonal.

\section{RESULTS AND DISCUSSION}

\subsection{Simulation results}

Figure 8 Shows the I-V and P-V characteristics of the photovoltaic module. This module consists of two groups, each group with 16 solar cells. The irradiance level on the first group (unshaded) is constant $\left(1000 \mathrm{~W} / \mathrm{m}^{2}\right)$, while the irradiance level on the second group (shaded) between 1000 and $0 \mathrm{~W} / \mathrm{m}^{2}$. Figure 8 (a) represents the I-V characteristics under the cases study in Table1. Figure 8 (b) illustrates the P-V characteristics of the same cases. From these results, it can be notice that the short circuit current decreases when the irradiance decreases, while the open circuit voltage is less affect by shading. The maximum power output decreases with decreasing in the shading factor. However, the output power is $88 \mathrm{~W}$ at Fs $=1$ and then dropped to $72.52,53.5,36.7,15.5$ and $11.86 \mathrm{~W}$ for $0.8,0.6,0.4,0,2$ and 0 of Fs respectively.

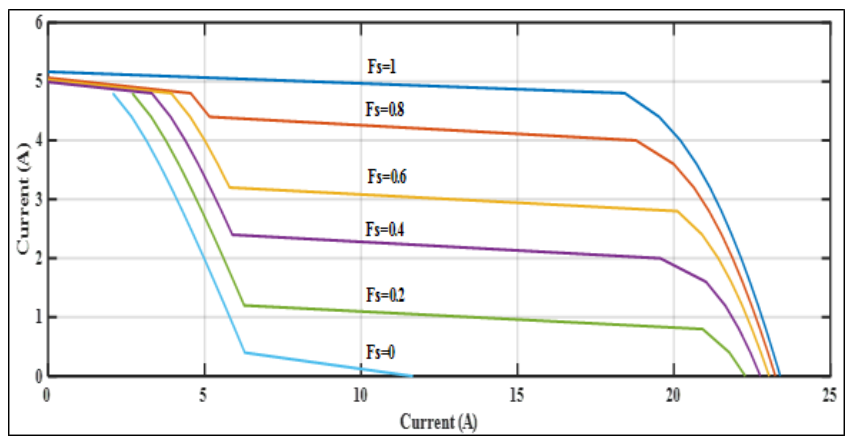

(a)

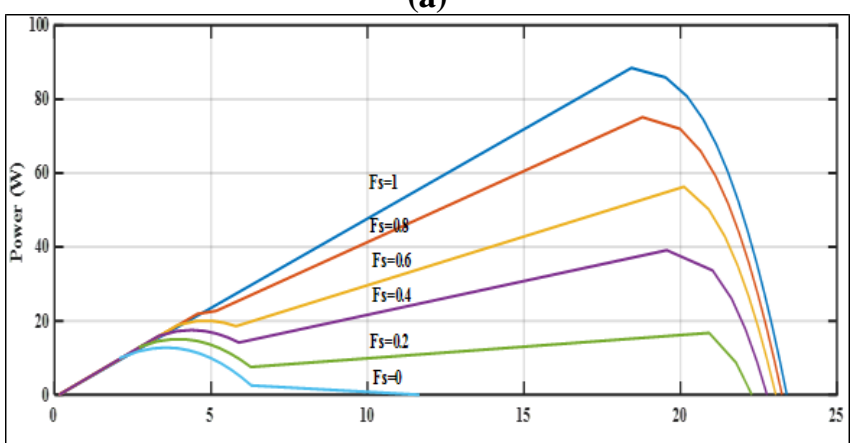

(b)

Figure 8. Photovoltaic module characteristics (a)I-V, (b)P-V.

When the irradiance on the module is non-uniform as illustrated in Table 2, multi steps in the I-V characteristics and multiple peaks in the $\mathrm{P}-\mathrm{V}$ characteristics curves are observed. This is because the bypass diodes are activated, where this bypasses the shaded group cells and allow the unshaded group cells to have different P-V characteristics from the shaded group cells. Figure 9 (a) shows the simulation results of the cases study in Table 2. The same figure shows that the short circuit current is negatively affected by decreasing the irradiance levels. This leads to decrease the maximum current and consequently, the 
maximum power as well, whereas the open circuit voltage is less affected by partial shading in comparing with short circuit current under these conditions. The maximum power values for these cases are 88, 76, 56.9, $33,44.3,29,16.1$ and $15 \mathrm{~W}$ for first, second, third, fourth, fifth, sixth, seventh, eighth case respectively.

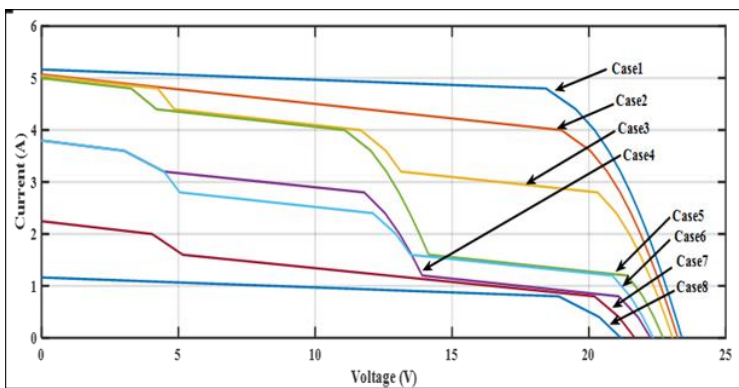

(a)

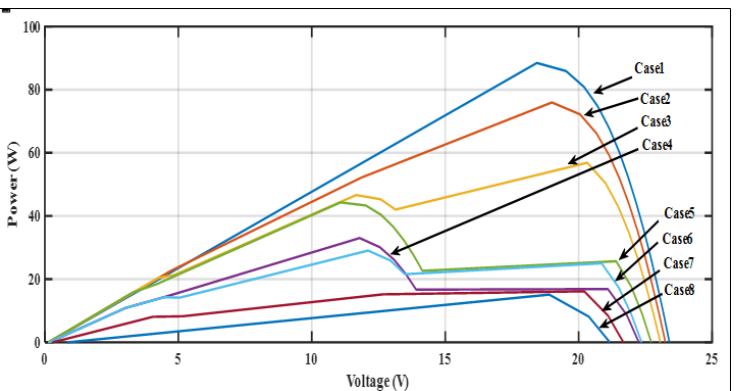

(b)

Figure 9. Photovoltaic module characteristics under nonuniform irradiation levels (a)I-V, (b)P-V.

\subsection{Experimental results}

An experiment was conducted to analyze the performance of PV panels under shading conditions. Figures 5, 6 and photo of Figure 7. Show the cases of shading with different shading area.

I. Horizontal string with $0,25,50,75$, and $100 \%$ shaded area.

II. Vertical String with $0,25,50,75$, and $100 \%$ shaded area.

III. Single cell with $0,25,50,75$, and $100 \%$ shaded area.

IV. Diagonal shading with multi step (one, two, three, and four steps).

Each case were applied on monocrystalline panel which shaded by $25,50,75,100 \%$ respectively under radiation changes between $(985 \pm 7 \mathrm{~W} / \mathrm{m} 2)$. In addition to that, the recorded environmental temperatures were close during measurement days. The outside temperature is $42 \pm 2^{\circ} \mathrm{C}$ while, the module temperature is approximately $66.2 \pm 2{ }^{\circ} \mathrm{C}$. In general Isc, Im decreasing with increasing shaded area, consequently Pm decreasing with increasing shading area as showed in Figure 10, Figure 11 and Figure 12. Figure (5.10) a and $\mathrm{b}$ show I-V and $\mathrm{P}-\mathrm{V}$ for different shading ratio of horizontal shading. Table 4 presents the Imax, Vmax, Pmax, $\Delta \mathrm{P}$, Plosses $(\Delta \mathrm{P} / \mathrm{P}(\%))$ and $\mathrm{FF}$ values which are calculated from Figure 10. Fill factor $(\mathrm{FF})$ is decreased from $70.61 \%$ to $0.42 \%$. It can. In comparison with current at no shading, the current is decreased by $98 \%$. The maximum power at no shading $63.45 \mathrm{~W}$ while, at $100 \%$ shading conditions, the power was drops to $0.504 \mathrm{~W}$. In the other words, the power decreased by $99.36 \%$ for $100 \%$ shading condition. In this case of shading, each string in the photovoltaic module affected by shading, therefore, the bypass diodes which connected between them completely disabled.

Case II: Vertical string shaded as previous case applied and the results explained in Figure 11. It can be noticed that the power output at $0 \%$ shading was $63.62 \mathrm{~W}$. While, at $100 \%$ shading condition, the power was decreased to $29.1 \mathrm{~W}$. In comparison with power at no shading, it mean that the power output dropped by $54.26 \%$ at $100 \%$ shading condition. At these condition, the F.F decreasing from $69.84 \%$ to $48.92 \%$.

Case III: In this case single cell shaded by $25 \%, 50 \%, 75 \%$ and $100 \%$, the result clarified in Figure 12. It can be noticed that at no shading (0\% shading) the current is $4.7 \mathrm{~A}$, however, at $100 \%$ shading conditions, the current was $2.81 \mathrm{~A}$. The same figure showed that the power at no shading is $63.87 \mathrm{~W}$, and then dropped to $26.33 \mathrm{~W}$. This means that power decreased by $68.71 \%$ as the shading increased to $100 \%$, as compared With power at no shading condition.

Table 4. The shading results of three cases

\begin{tabular}{|c|c|c|c|c|c|c|c|c|c|}
\hline \multirow{2}{*}{$\begin{array}{c}\text { Shading } \\
\text { Area } \\
\text { (SA) }\end{array}$} & \multicolumn{3}{|c|}{$\begin{array}{c}\text { Horizontal string Shading } \\
\text { Case I }\end{array}$} & \multicolumn{3}{|c|}{ Vertical string Shading Case II } & \multicolumn{3}{|c|}{$\begin{array}{c}\text { Single cell Shading } \\
\text { Case III }\end{array}$} \\
\hline & $\begin{array}{l}\Delta \mathrm{P} \\
(\mathrm{W})\end{array}$ & $\mathrm{P}_{\text {losses }}(\%)$ & $\begin{array}{l}\text { F.F } \\
(\%)\end{array}$ & $\begin{array}{l}\Delta \mathrm{P} \\
(\mathrm{W})\end{array}$ & $\mathrm{P}_{\text {losses }}(\%)$ & $\begin{array}{l}\text { F.F } \\
(\%)\end{array}$ & $\begin{array}{l}\Delta \mathrm{P} \\
(\mathrm{W})\end{array}$ & $\mathrm{P}_{\text {losses }}(\%)$ & $\begin{array}{l}\text { F.F } \\
(\%)\end{array}$ \\
\hline $0 \%$ & 0 & 0 & 70.61 & 0 & 0 & 69.17 & 0 & 0 & 70.5 \\
\hline $25 \%$ & 21.11 & 33.27 & 67.62 & 17.09 & 26.86 & 50.24 & 16.9 & 26.46 & 57.04 \\
\hline $50 \%$ & 36.78 & 57.96 & 63.43 & 20.15 & 31.67 & 50.07 & 21.69 & 33.96 & 50.04 \\
\hline $75 \%$ & 51.44 & 81.07 & 54.31 & 23.37 & 36.73 & 47.78 & 26.43 & 41.38 & 45.47 \\
\hline $100 \%$ & 62.95 & 99.21 & 0.4 & 34.52 & 54.26 & 48.92 & 37.5 & 58.71 & 49.3 \\
\hline
\end{tabular}




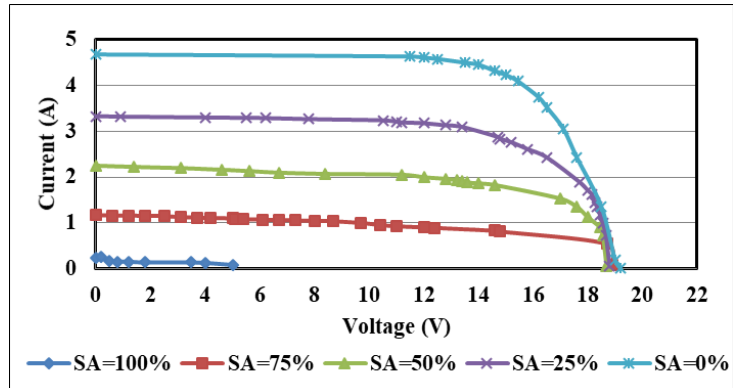

(a)

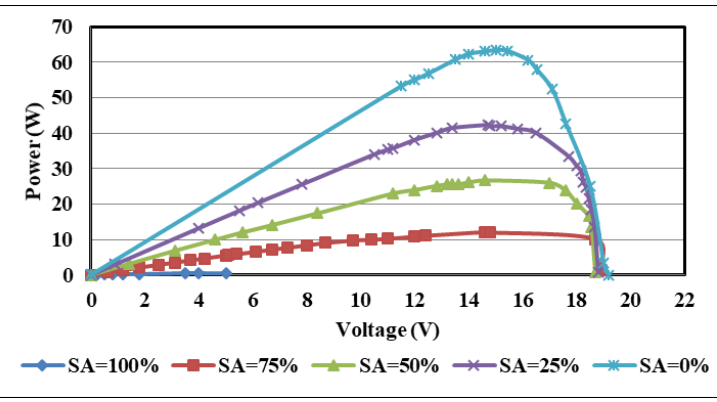

(b)

Figure 10. Recorded characteristics of PV panel under horizontal string shading (a) I-V; (b) P-V.

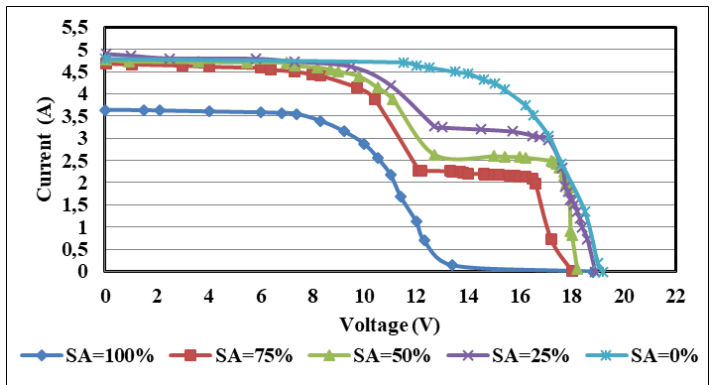

(a)

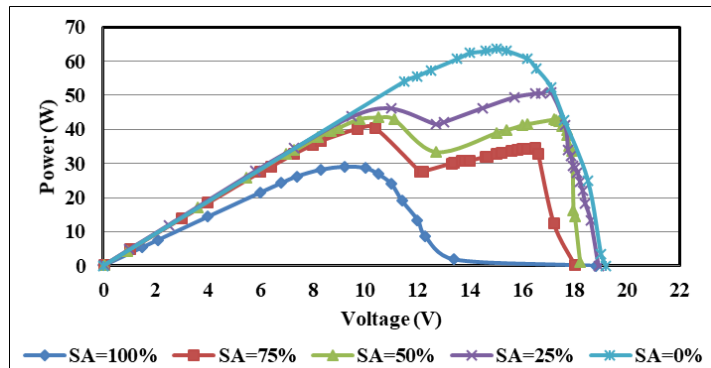

(b)

Figure 11. Recorded characteristics of PV panel under vertical string shading (a) I-V; (b) P-V.

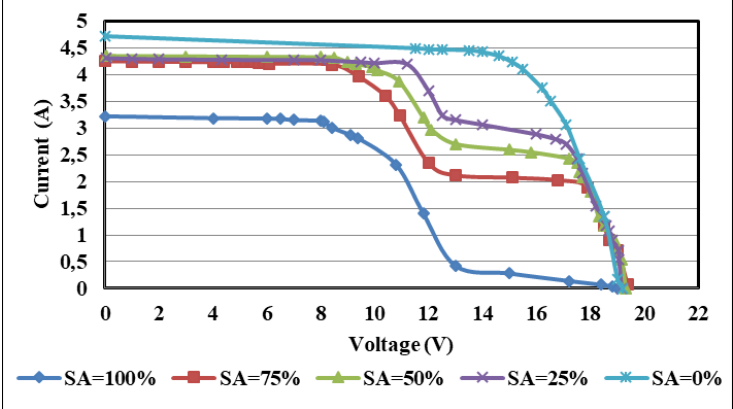

(a)

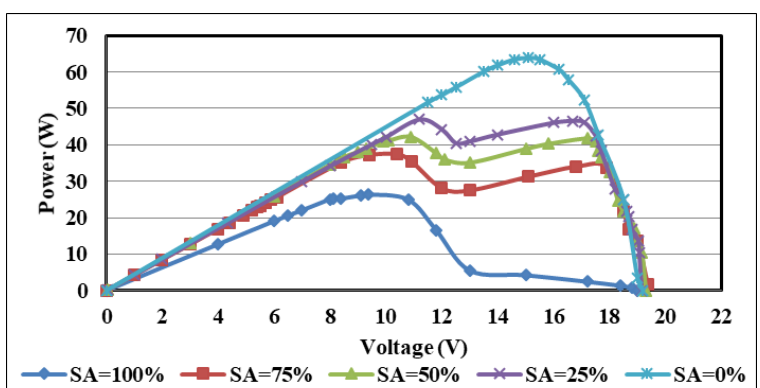

(b)

Figure 12. Recorded characteristics of PV panel under single cell shading(a) I-V; (b) P-V.

By comparing the results of the three cases, it can be concluded that the decreasing in maximum power output in the third case is less than the decreasing in the first cases (horizontal and vertical shading). Diagonally shading with multi step (one, two, three, and four steps) investigating at $860 \mathrm{~W} / \mathrm{m} 2$ radiation level, as illustrated in Figure (5.19a \& b). The results of this type of shading appeared that in the first step where no shading applied the Im was 4.38 , then it decreased to1.9, 4.11, and 2.11A for second, third and fourth steps. On the other hand he power dropped from $61.32 \mathrm{~W}$ at no shading to $2.43 \mathrm{~W}$ for the fourth steps.

The comparison is done for two cases random reading for no shading condition and $100 \%$ of vertical string shading when solar radiation is $743 \mathrm{Wlm}^{2}$ and module temperature is $57^{\circ} \mathrm{C}$. The $\mathrm{I}-\mathrm{V}$ and $\mathrm{P}-\mathrm{V}$ curves of the collected data that were achieved experimentally and theoretically are explained in the Figures $14 \mathrm{a}$ and $\mathrm{b}$. The error between the experimental and theoretical results is about 3.3 and $6.28 \%$ for first and second cases respectively.

A comparison between present experimental results of power losses of PV module as a function of shading area with the experimental results of previous studies explained in Figure 15. This figure presented a 
comparison of the present work with F. Bayrak et al [23]. It can be observed that the present experimental results have obvious agreement in the behavior as compared with the existing literature.

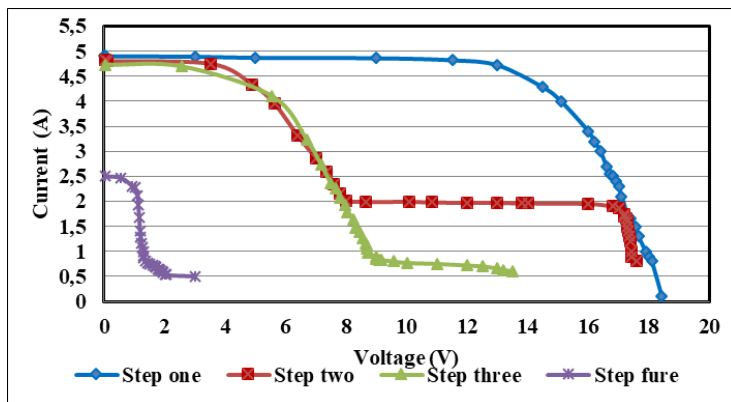

(a)

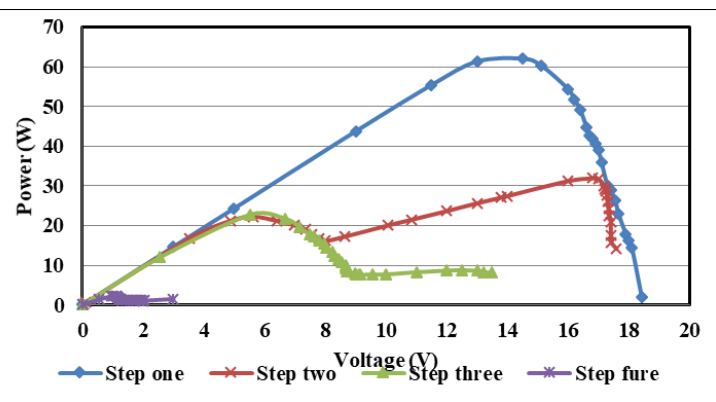

(b)

Figure 13. Recorded characteristics of PV panel under diagonally shading (a) I-V; (b) P-V.

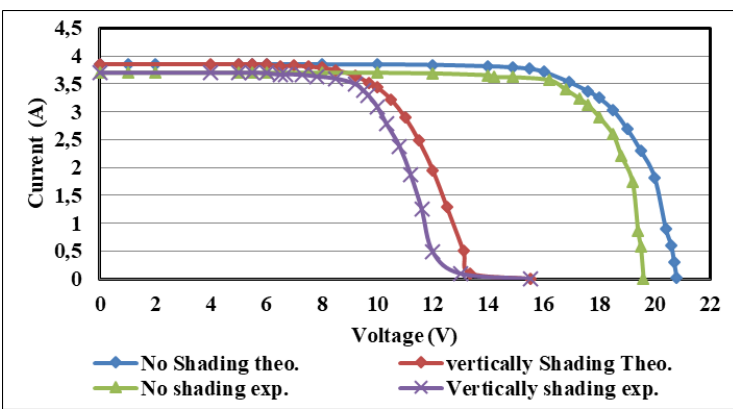

(a)

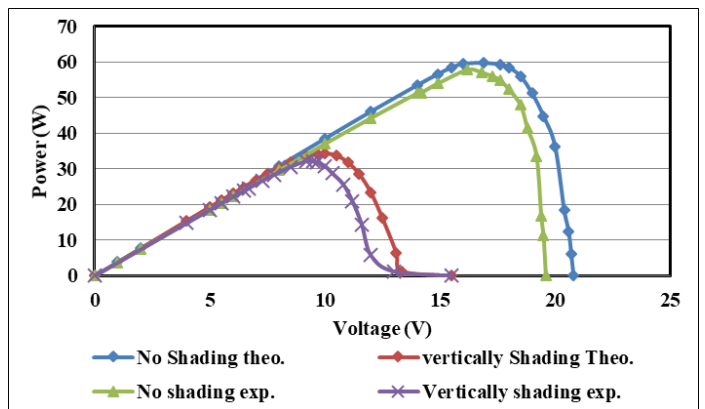

(b)

Figure 14. Recorded characteristics of theoretical and experimental results for no shading and $100 \%$ vertical string shading. (a) I-V; (b) P-V.

\section{CONCLUSION}

In this paper, non- transparent material with different shading position and different percentage of area are applied on monocrystalline solar panel. The importance of the presence of diodes in the PV panels is their ability to divide each panel into several sections. The results showed that the Photon current under partial shading decreases. This reduces Isc and Im, which leads to decrease the output power. Besides, the results reveals that when the radiation changes between 965 to $975 \mathrm{~W} / \mathrm{m} 2$ and $100 \%$ shading condition is considered the power decreases by $99.36 \%, 43.7 \%$ and $41.15 \%$ for horizontal, single cell, and vertical respectively comparing with their initial value at no shading condition. Further, when considering the diagonal shading with no shading at first step the power is $62.06 \mathrm{~W}$. However, the power decreases by 48.56 $\%, 63.3 \%$ and $96.22 \%$ for second, third and fourth steps respectively. The parameters of PV panel are simulated by using MATLAB to investigate the partial shading effect at different irradiation levels. The results show noticeable agreement between the experimental and the theoretical results.

\section{REFERENCES}

[1] T. Esram and P. L. Chapman, "Comparison of Photovoltaic Array Maximum Power Point Tracking Techniques," IEEE Transactions Energy Conversion, vol. 22, pp. 439-49, 2007.

[2] N. S. Nazri, et al., "Energy Economic Analysis of Photo-Voltaic-Thermal-Thermoelectric (PVT-TE) Air Collectors," Renewable and Sustainable Energy Review, vol. 92, pp. 187-97, 2018.

[3] S. Adnan, et al., "Solar energy potential in Pakistan," Journal of Renewable and Sustainable Energy, vol. 4, pp. 17, 2012.

[4] G. Pilawjian, "Analysis of Photovoltaic Concentrating Solar Energy Systems," ARPN Journal of Systems and Software, vol. 2, pp. 110-112, 2012.

[5] F. Fadliondi et al., "Bypass Diodes for Improving Solar Panel Performance," International Journal of Electrical and Computer Engineering, vol. 8, pp. 2703-2708, 2018. 
[6] J.M. Carrasco et al., "Power-electronic systems for the grid integration of renewable energy sources: A survey," IEEE Transactions on industrial electronics, vol. 53, pp. 1002-1016, 2006.

[7] J. Krautmann and J. Zhu, "Photovoltaic Solar Energy Systems: Market Trends in the United States," International Journal of Applied Power Engineering, vol. 1, pp. 123-128, 2012.

[8] M. Z. Shams El-Dein, et al., "Optimal photovoltaic array reconfiguration to reduce partial shading losses," IEEE Trans. Sustain.Energy, vol. 4, 2013.

[9] K. Sundareswaran et al., "MPPT of PV systems under partial shaded conditions through a colony of flashing fireflies," IEEE Trans. on Energy Convers, vol. 29, no. 2, 2014.

[10] S. Malathy and R. Ramaprabha, "Comprehensive analysis on the role of array size and configuration on energy yield of photovoltaic systems under shaded conditions," Renewable and Sustainable Energy Reviews, vol. 49, pp. 672-679, 2015.

[11] A. Ndiaye et al., "Impact of dust on the photovoltaic (PV) modules characteristics after an exposition year in Sahelian environment: The case of Senegal," International Journal of Physical Sciences, vol. 8, pp. 1166-1173, 2013.

[12] F. Dincer and M. E. Meral, "Critical Factors that Affecting Efficiency of Solar Cells," Smart Grid and Renewable Energy, vol. 1, pp. 47-50, 2010.

[13] N. Milind et al., "Enhancing the Efficiency of Solar Panel Using Cooling Systems," International Journal of Engineering Research and Applications, vol. 7, pp. 5-7, 2017.

[14] K. S. Parlak, "PV array reconfiguration method under partial shading conditions," Electer. Power Energy Syst., vol. 63, pp. 713-721, 2014.

[15] H. Patel and V. Agarwal, "MATLAB-Based Modeling to Study the Effects of Partial Shading on PV Array Characteristics," IEEE Trans. on Energy Convers, vol. 23, pp. 302-310, 2008.

[16] M. C. Alonso-Garcia, et al., "Computer simulation of shading effects in photovoltaic arrays," Renewable energy, vol. 31, no. 12, pp. 1986-1993, 2006.

[17] D. Rossi et al., "Modeling and Detection of Hotspot in Shaded Photovoltaic Cells," IEEE Transactions on Very Larrge Scale Integration (VLSI) Systems, vol. 23, pp. 1063-8210, 2015.

[18] G. Cipriani, et al., "Reconfiguration strategies to reduce mismatch effects on PV array: an Arduino-based prototype," Int.Symp. Power Electronics', Electrical Drives, Automation and Motion (SPEEDAM), pp. 1003-1008, 2014

[19] S. Silvestre, et al., "Study of bypass diodes configuration on PV modules," Appl. Energy, vol. 86, pp. 1632-1640, 2009.

[20] H. H. Khaing, et al., "Characteristics of Different Solar PV Modules under Partial Shading," International Journal of Energy and Power Engineering, vol. 8, pp. 1418-1422, 2014.

[21] G. S. Reddy, et al., "A MATLAB based PV Module Models analysis under Conditions of Nonuniform Irradiance, " Energy Procedia 974-2017-983 ,1st International Conference on Power Engineering, Computing and Control, PECCON-2017, 2-4 March 2017, VIT University, Chennai Campus, 2017.

[22] M. A. Al Mamun, et al., "Experimental investigation of the effect of partial shading on photovoltaic performance," IET Renewable Power Generation, vol. 11, pp. 912-921, 2017.

[23] F. Bayrak, et al., "Effects of partial shading on energy and exergy efficiencies for photovoltaic panels," Journal of Cleaner Production, vol. 164, pp. 58-69, 2017.

[24] A. G. Alonso, et al., "Shading Ratio Impact on Photovoltaic Modules and Correlation with Shading Patterns," MDPI. Energies, vol. 11, pp.1-26, 2018.

[25] J. C. Teo, et al., "Impact of Partial Shading on the P-V Characteristics and the Maximum Power of a Photovoltaic String," MDPI Energies, vol. 11, 2018.

[26] A. A. Elbaset and M.S. Hassan, "Design and Power Quality Improvement of Photovoltaic Power System," Springer, International Publishing AG, Switzerland, 2017.

[27] Y. Cascone, et al., "Calculation procedure of the shading factor under complex boundary conditions," Solar Envergy, vol. 85, pp. 2524-2539, 2011. 